\title{
A critical review of against intellectual monopoly
}

\author{
John Kennedy
}

Published online: 6 October 2010

(C) The Author(s) 2010. This article is published with open access at Springerlink.com

Against Intellectual Monopoly, by Michele Boldrin and David Levine (2007), is a coherent, well-written, and persuasive argument against strong forms of government protection of intellectual property rights. The authors contend that intellectual property rights do not generally promote social welfare, that intellectual property protection generates perverse distributional outcomes, and that firms do not respond to greater levels of protection of intellectual property protection by actually producing more innovation or, if they do, such additional creation is not socially optimal. Although generally quite sound, the book is not without problems; its normative judgments of drug companies are wildly overstated, and the first-mover argument does not adequately address the virtually instantaneous availability of many copyrighted goods online. The book is not written from an Austrian perspective per se, but does extend the logic of the benefits of competitive markets to non-physical goods, and draws conclusions that libertarians are likely to welcome.

The authors hold that major technological progress occurs more or less spontaneously as a result of individuals making incremental changes to improve products and processes, and that the financial incentives generated by intellectual property monopoly do not significantly fuel innovation. The authors persuasively argued this point in many parts of the book, and provide dozens of strong supporting examples of how intellectual monopoly probably slows technological change. They also provide examples of markets that flourished because of an absence of strong intellectual property rights: Hollywood emerged as the global leader in film production because it was too remote for Washington to enforce Edison's patents there, the German chemical engineering political action group's campaign against domestic patenting laws while actively encouraging patent laws in rival countries, the fast-paced and generally highly responsive fashion markets, the growth of Silicon Valley as the hub of IT innovation instead of Route 128 because California would not enforce non-compete labor agreements, etc. The sheer number of anecdotes presented in support of their argument-industries harmed by strong intellectual property, industries which

J. Kennedy $(\square)$

San José State University, One Washington Square, San José CA, USA

e-mail: johnkennedy5386@yahoo.com 
flourished because of the creative destruction promoted by the competitive environments associated with zero intellectual property - is persuasive.

Boldrin and Levine (2007) hold a lot of creative work inspired by selfactualization and first-mover advantages. They challenge the notion of the individual creator working for all hours of the night to solve a big problem with financial incentives at the forefront of his or her mind. The authors hold that first-mover advantages in materials that are today copyrighted are sufficient financial motivation for the production of creative works. They support this view with many persuasive anecdotes from film, books, and music.

The authors do not think the ending of copyright will lead to a significant decline in production of creative works. Although the monopoly gains from copyright will be smaller, the scale of the market is also likely to grow larger as IP laws are relaxed, which in aggregate has an ambiguous impact. This is obviously a subjective assertion based almost entirely on rationale and not on evidence, and it is uncertain how one could really establish this point in the face of a cogent counter-claim.

The empirical evidence presented by Boldrin and Levine (2007) is also persuasive. If starting from a position of moderate levels of intellectual property protection, generating stronger intellectual property rights does not generate greater levels of creative work, substantive research, or economic growth. The only thing that stronger patent laws have been shown to generate is more patents and more lawsuits.

The authors repeatedly argue that first-mover advantages allow companies to take advantage of economies of scale in manufacturing, and that impatience effects will generate brief monopoly profits early after the release of goods that are currently protected by copyright. This argument has conceptual problems.

While this is probably true of patents - they largely establish that this advantage is present in physical goods with logic and an overwhelming number of anecdotes - this does not likely hold for nonphysical goods capable of being shared over peer to peer networks. Pirated versions of video games, movies, and music are often available on the day of release ${ }^{1}$ on popular torrent websites, and the only difference between the illegally downloaded versions of games and music is that end-users do not receive the physical DVD, CD, or packaging associated with purchased goods. This largely eliminates first mover and impatience effects that the authors suggest would be financial incentive enough to incentivize production of movies, books, and games.

The authors could have strengthened their zero-copyright argument with a separate assertion. Several companies have pursued successful strategies in de facto intellectual property vacuums. Microsoft often ignores end-user piracy to gain market share, Blizzard creates products that are difficult to pirate and provides compelling product updates, the Grateful Dead employed an eclectic approach to IP enforcement, and South Park provides its goods at zero monetary cost and streams advertisements. And most DVD and CD companies are differentiating their products with special editions, unique art, and accessory goods. ${ }^{2}$ Companies can find ways to generate revenue from their ideas in the absence of intellectual property protection, they just have to continually innovate and adapt to often fickle consumer preference in order to do so. That many firms would prefer not to do so is unsurprising.

\footnotetext{
${ }^{1}$ As of the date of this writing, PirateBay is currently hosting Iron Man 2 prior to its release in theaters.

${ }^{2}$ See collectors editions of Terminator 2, Metallica's Greatest Hits, or Lord of the Rings
} 
Some of Boldrin and Levine's (2007) normative conclusions are plainly not supported. The authors literally compare the CEOs of drug companies to Hitler and Stalin for failing to provide their goods at zero profit to individuals in Africa. Restraining the production of drugs that lengthen the lives of people with HIV and AIDS in order to earn economic rents is clearly not an act of altruism, but nor is it the moral equivalent of mass political killings. That one is not Oscar Schindler does not mean one is Adolf Hitler.

Measurement problems abound in attempting to quantify the relationship between macrotechnology and intellectual protection, so the empirical research is somewhat limited. Outside research largely confirmed the arguments presented by Boldrin and Levine (2007). The Trading With the Enemy Act of 1917, which basically eliminated all intellectual property in the US previously held by Germans or German companies, clearly increased innovation (Moser and Voena 2009). The FTC and DOJ effort to weaken patents in telephone and copy machinery also clearly had a positive impact on innovation (Breshanan 1985). Further research in this area is clearly needed; however, the research that has taken place in this field largely confirms the authors' arguments.

Work in social psychology-admittedly trending more towards scientific innovation and artistic creativity than entrepreneurial activity — on this issue almost completely ignores profits. Views of innovation and creativity in the field ${ }^{3}$ emphasize random elements, self-actualization, theories progressively building on one another, of the lone exceptionally high-IQ genius, of zeitgeist, of other minority views, and syntheses of these views. Monopoly profits - and economic incentives generally - are not seen as the dominant force in innovation. This literature has neglected entrepreneurs to a certain extent, but it seems unlikely that we will miss the next Newton or Vivaldi because of insufficient intellectual property rights.

Reviewing the literature in social psychology and economics, innovation appears to be a function of chance, self-actualization, spontaneous discovery, a zeitgeist which fosters robust competition, profits, and informal social payoffs. The importance of each factor probably varies by discipline-profits are likely a greater motivator in the creation of new prescription drugs and commercial art than in poetry or social science. Boldrine and Levine (2007) integrate the complexity of likely determinants of innovation into their argument, while supporters of strong forms of intellectual property rights have often wildly overstated the importance of profits.

The limited empirical evidence, and the strongest arguments presented by the authors, suggests that a limited degree of intellectual property protection would be the most efficient. The first mover argument falls apart for many copyrighted goods, the authors have no fully established the negative long run economic consequences of limited-term patent protection of prescription drugs, but the rest of their arguments are very sound and the empirical evidence generally supports their positions.

The authors admit that some intellectual property likely promotes welfareenhancing innovation, but assert that any degree of intellectual property protection will trigger rent seeking, and that this rent seeking will generate public choice problems that will ultimately lead to a strong-form IP state. This assertion is not without at least a degree of merit. ${ }^{4}$ In the end, it appears that the choice between a

\footnotetext{
${ }^{3}$ One summary of this research is Greatness: Who Makes History and Why by Dean Simonton (1994).

${ }^{4}$ See the petition by certain vested interests in the fashion industry to make fashion design subject to intellectual property: http://www.copyright.gov/docs/regstat072706.html
} 
low level of intellectual property protection and no intellectual property protection is whether one considers the welfare-enhancing effect of some intellectual property protection greater than the public choice risks. Whether public choice problems are tendency or destiny is far too broad a question for this paper. Although imperfect, Against Intellectual Monopoly is a fascinating and provocative read.

Open Access This article is distributed under the terms of the Creative Commons Attribution Noncommercial License which permits any noncommercial use, distribution, and reproduction in any medium, provided the original author(s) and source are credited.

\section{References}

Boldrin, M., \& Levine, D. (2007). Against intellectual monopoly. Accessed at http://levine.sscnet.ucla.edu/ general/intellectual/against.htm. Accessed on February 27, 2010.

Breshanan, T. (1985). Post-entry competition in the plain paper copier market. American Economic Review, 75, 2.

Moser, P., \& Voena, A. (2009). Compulsory licensing: evidence from the trading with the enemy act. Stanford University Working Paper.

Simonton, D. (1994). Greatness: Who makes history and why. The Gulliford Press. 